\title{
Treatment of juvenile idiopathic arthritis: a revolution in care
}

\author{
Matthew L Stoll ${ }^{*}$ and Randy Q Cron
}

\begin{abstract}
A generation ago, children with arthritis faced a lifetime of pain and disability. Today, there are a multitude of treatment options, including a variety of biologics targeting key cytokines and other inflammatory mediators. While non-steroidal anti-inflammatory drugs and corticosteroids were once the mainstay of therapy, they are now largely used as bridge or adjunctive therapies. Among the conventional disease-modifying anti-rheumatic drugs, methotrexate remains first-line therapy for most children with juvenile idiopathic arthritis (JIA) due to its long track record of safety and effectiveness in the management of peripheral arthritis. Sulfasalazine and leflunomide may also have a secondary role. The tumor necrosis factor inhibitors (TNFi) have shown tremendous benefit in children with polyarticular JIA and likely in enthesitis-related arthritis and psoriatic JIA as well. There may be additional benefit in combining TNFi with methotrexate. Abatacept and tocilizumab also appear to benefit polyarticular JIA; the role of rituximab remains unclear. For the treatment of systemic JIA, while the TNFi are of less benefit, blockade of interleukin-1 or interleukin-6 is highly effective. Additionally, interleukin-1 blockade appears to be effective treatment of macrophage activation syndrome, one of the most dangerous complications of JIA; specifically, anakinra in combination with cyclosporine and corticosteroids may obviate the need for cytotoxic approaches. In contrast, methotrexate along with the TNFi and abatacept are effective agents for the management of uveitis, another complication of JIA. Overall, the biologics have demonstrated an impressive safety record in children with JIA, although children do need to be monitored for rare but potentially dangerous adverse events, such as tuberculosis and other infections; paradoxical development of additional autoimmune diseases; and possibly an increased risk of malignancy. Finally, there may be a window of opportunity during which children with JIA will demonstrate most optimal responses to aggressive therapy, underscoring the need for rapid diagnosis and initiation of treatment.
\end{abstract}

Keywords: Juvenile idiopathic arthritis, Treatment, Safety, Effectiveness

\section{Introduction}

A generation ago, children with arthritis were fortunate if they could find a rheumatologist to treat them, and even with the best therapies available at the time, often faced a childhood of pain and disability. Today, we are able to combine old and new therapies to improve dramatically the outlook of children with juvenile idiopathic arthritis (JIA). In this review, we will summarize treatment options for children with JIA, emphasizing the safety as well as the effectiveness of many new and old therapies.

\footnotetext{
* Correspondence: mstoll@peds.uab.edu

University of Alabama at Birmingham, CPP N 210 M, 1600 7th Avenue South, Birmingham, AL 35233-1711, USA
}

\section{() Biomed Central}

\section{Review \\ Subtypes of JIA} known etiology presenting before the $16^{\text {th }}$ birthday and lasting at least six weeks [1]. There is evident heterogeneity with respect to clinical, demographic, and genetic features among the JIA subtypes, translating into heterogeneity in the responses to treatment (Table 1) [2].

Treatment of JIA

Nonsteroidal anti-inflammatory drugs (NSAIDs)

A generation ago, the "pyramid approach" used for management of JIA and rheumatoid arthritis (RA) devoted extensive space to NSAIDs and other analgesics [3]. Currently, as there is greater awareness of the long- 
Table 1 JIA subtypes ${ }^{\S}$

\begin{tabular}{|c|c|c|c|c|c|c|}
\hline Feature & Oligoarticular & RF - polyarticular & RF + polyarticular & Systemic & ERA & Psoriatic \\
\hline Peak age of onset & $1-3$ years & Dual peaks & Teenage & 2 years & Teenage & Dual peaks \\
\hline Sex & $F>M$ & $F>M$ & $F>M$ & Equal & $M>F$ & ${ }^{*} \mathrm{~F}>\mathrm{M}$ \\
\hline ANA+ & Majority & Majority & Rare & Rare & Rare & Majority of younger age \\
\hline $\mathrm{RF}+$ & No & No & Yes & No & No & No \\
\hline HLA-B27+ & No & No & No & No & Majority & Majority of older age \\
\hline Uveitis & Silent & Silent & Rare & Rare & Typically acute & Silent \\
\hline Enthesitis & No & No & No & No & Yes & Older age \\
\hline Dactylitis & Rare & No & No & No & Yes & Yes \\
\hline Fevers & No & No & No & High-spiking & No & No \\
\hline
\end{tabular}

${ }^{\varsigma}$ By definition, children with unclassified JIA meet criteria for none or for two or more of the categories listed in the table. ${ }^{*}$ Among psoriatics with an older age of onset, the male: female ratio is close to 1, and the incidence of positive ANA is lower. Abbreviations: ERA - enthesitis related arthritis. Adapted from [2].

term course and outcome of the diseases and the need for improved control [4], recent recommendations give less emphasis to NSAIDs; specifically, use of NSAIDs as mono-therapy for more than two months was discouraged if arthritis was still active [5]. The relative benefit to side effect ratio of NSAIDs is rather low in treating childhood arthritis, particularly in comparison to novel biologic agents now available.

\section{Oral corticosteroids (CS)}

Like NSAIDs, oral CS were once a mainstay of therapy, with current recommendations largely silent on their use [5]. Although novel therapies have enabled practitioners to reduce corticosteroid usage (Mannion, manuscript under revision for $J$ Rheumatol), registry data in 2012 indicated that their use remained quite frequent, ranging by subtype from $3-22 \%$ for current usage at the time of enrolment into the registry and $21-83 \%$ for any usage [6].

\section{Intra-articular CS (IACS)}

IACS are a mechanism of providing local and longlasting effective therapy to patients, thus providing in many cases very rapid relief of symptoms and potentially sparing the requirement of systemic therapy among patients with persistent oligoarticular arthritis [7]. Among the IACS preparations, a randomized controlled trial (RCT) of children with bilateral knee arthritis revealed that triamcinolone hexacetonide resulted in longer-lasting remission compared to triamcinolone acetonide [8]. Although use of IACS may be less frequent in the current biologic era, in some cases, particularly among patients with arthritis involving the temporomandibular joint (TMJ), active TMJ arthritis can persist even in otherwise quiescent disease and despite aggressive use of systemic therapy for arthritis [9]. Additional therapy is important since ongoing TMJ arthritis frequently results in micrognathia and facial dysmorphism [10].

\section{Conventional DMARDs Methotrexate (MTX)}

Methotrexate remains the most widely used conventional DMARD in the management of JIA [6,11]. Its efficacy was initially established over 20 years ago in a collaborative study between the United States and the then Soviet Union [12]. Although the role of conventional DMARDs in patients with spondyloarthritis (SpA) is unclear [13], MTX is recommended as initial therapy in all JIA subtypes, following a trial of NSAIDs or IACS in children with mild oligoarticular JIA (oJIA) [5]. The only exception consists of patients with sacroiliitis alone, in whom pediatric and adult guidelines recommend skipping conventional DMARDs [5,14]. MTX can be given both orally and subcutaneously (SQ). A recent retrospective study demonstrated no differences in effectiveness between the routes of administration among patients who remained on MTX monotherapy [15]. However, limitations of this study included different baseline characteristics of the patient groups, exclusion of children who either switched from oral to SQ or vice versa, and exclusion of children who required addition of a biologic. Other studies have shown increased bioavailability of SQ compared to oral MTX at higher doses [16], as well as improvement upon switching from oral to SQ administration [17]. Dose escalation among patients receiving SQ methotrexate was not shown to be of benefit, as a RCT of children with JIA who had an incomplete response to $15 \mathrm{mg} / \mathrm{m}^{2}$ SQ did not demonstrate improved response at $25 \mathrm{mg} / \mathrm{m}^{2}$ compared to being maintained at the same dose [18]. In addition, in a cohort analysis, higher doses of methotrexate did not significantly improve joint counts [19]. Nevertheless, MTX is effective and typically well-tolerated by children, with most of the AEs affecting the gastrointestinal tract; monitoring of blood counts and liver tests is also required [5].

\section{Sulfasalazine (SSZ)}

Like MTX, SSZ has long been used as therapy for JIA. A RCT of children with oligoarticular and polyarticular 
arthritis demonstrated it to be superior to placebo [20], and long-term follow-up of the trial showed that the children initially treated with SSZ fared better than those initially treated with placebo at a median of 9 years after the study [21]. SSZ has never been compared head-tohead with MTX in treating JIA. However, indirect comparisons show that MTX appears to be better tolerated and may be more effective in most patients without enthesitis-related arthritis (ERA) [22,23]. Thus, current guidelines support its use in ERA, but not in other types of JIA [5]. In particular, SSZ has been shown to be associated with high toxicity in adult-onset Still disease [24] and thus should probably be avoided in children with the related condition of SJIA [25].

\section{Other conventional DMARDs}

Multiple DMARDs used to treat adults with rheumatoid arthritis, including leflunomide, azathioprine, cyclosporine, and hydroxychloroquine, are used infrequently in pediatric subjects. Leflunomide may have similar effectiveness and safety as MTX and is likely a good alternative for patients who cannot tolerate MTX [26], but its teratogenicity and long half-life is a concern in pediatric patients. The other DMARDs generally have shown less effectiveness and, with the exception of hydroxychloroquine (HCQ), increased risk of adverse events [27-31].

\section{Biologics \\ Overview}

At present time, there have been 16 randomized, controlled trials (RCTs) of biologics in the treatment of children with JIA [32-46]. With few exceptions, the studies have demonstrated that biologics are highly effective and safe in the treatment of JIA, and have propelled us into a new era of management.

\section{Introduction and effectiveness \\ Tumor necrosis factor inhibitors (TNFi): etanercept and monoclonal antibodies}

The cytokine TNF was first linked to RA in the 1980s [47], and elevated levels of TNF have been reported in JIA patients as well [48]. Five TNFi are commercially available, of which three - adalimumab, etanercept, and infliximab have been extensively used in children with JIA. Etanercept is a fusion protein consisting of the extracellular domain of the p75 TNF receptor, linked to the Fc region of human IgG1 [49], thus serving as a trap for soluble TNF. In contrast, adalimumab and infliximab are monoclonal antibodies against TNF: the former is fully humanized, while the latter is a chimeric molecule with murine and human components [50]. Among the TNFi, infliximab is administered intravenously, while the rest are administered subcutaneously.
RCT of both etanercept and adalimumab demonstrated TNFi to be effective therapeutic options for children with polyarticular course JIA, with withdrawal studies demonstrating fewer flares among the drug- versus placebotreated patients [32,36]. Surprisingly, a RCT of infliximab did not meet its primary aim, which was a statistically significant difference in the composite pediatric American College of Rheumatology-30 response at 14 weeks [34]. A more recent study, in which children were randomized to receive either infliximab plus methotrexate, or combination therapy of three conventional DMARDs (MTX, SSZ, and HCQ), did favor infliximab therapy [40]. The reasons for the discrepancy are unclear, although it could relate to the low numbers, short trial duration, or low dosage used in the unsuccessful study, as well as the unusually high placebo response rate in that study. Thus, most practitioners consider all three of these TNFi to be viable options. One particular advantage of infliximab therapy is the ease with which the dose can be escalated, without subjecting patients to additional sometimes painful injections. Although the effectiveness of this approach remains to be elucidated, it has recently been demonstrated that doses as high as $20 \mathrm{mg} / \mathrm{kg} /$ dose every two weeks can be safely administered to children with JIA [51].

As noted above, JIA is a heterogeneous condition, with multiple distinct subtypes. Thus, efficacy in one category does not necessarily translate into a different group. The above studies included children with polyarticular course JIA, which generally includes patients with extended oJIA, Rheumatoid Factor (RF)- polyarticular JIA (pJIA), RF + pJIA, and systemic JIA (sJIA) without active systemic features at the time of the study. Excluded were children with ERA, psoriatic JIA (psJIA), and sJIA with active systemic symptoms. Open-label studies of TNFi in ERA [52-54] as well as one RCT [41] appear to show effectiveness. Likewise, the data in psJIA appears promising [55]. In contrast, an open-label study of etanercept in JIA as well as the German etanercept registry have both shown less of a response in patients with sJIA as compared to those with oligoarticular or polyarticular onset [56,57]. Notably, this was not seen in the RCTs: although none were powered to analyze response by JIA category, the initial etanercept RCT [32] demonstrated similar incidence of flares among sJIA as compared to other subjects, and the abatacept RCT [35] likewise demonstrated a similar response in the open-label phase of the study. The reasons for the discrepancies between the open-label and RCT studies are unclear, although as discussed below, the course of sJIA appears to have distinct phases, potentially translating into differences in response to therapy. Below, the role of IL-1 and IL- 6 blockade in sJIA will be addressed.

As reflected in the study design of the majority of the RCTs involving TNFi in children with pJIA, most practitioners combine TNFi with MTX or other non-biologic 
DMARDs, when tolerated. Data from the German etanercept registry supports this practice, as children taking etanercept plus MTX demonstrated improved treatment responses as compared to those taking etanercept alone, without an increase in AEs [58]. There are no randomized studies comparing TNFi as monotherapy versus combination therapy, nor is there any data supporting combinations of TNFi with additional biologics, combinations which have raised safety concerns in adult studies $[59,60]$.

\section{Interleukin-1 inhibitors}

Interleukin-1 (IL-1) is a highly pro-inflammatory cytokine that appears to play a role in a variety of inflammatory conditions [61]. Three different IL-1 antagonists currently exist in the marketplace, and all 3 are administered subcutaneously (anakinra, canakinumab, and rilonacept). Anakinra is an analogue to the naturally-occurring interleukin-1 receptor antagonist; rilonacept is a soluble fusion protein consisting of human IgG1 linked to the IL-1 receptor and accessory protein; and canakinumab is a monoclonal antibody directed against IL-1 $\beta$ [61].

The first indication that IL-1 blockade may be promising in children with sJIA was provided by Verbsky and White, who successfully treated two children with anakinra [62]. Since then, multiple additional case series have confirmed its effectiveness [63-65], as have RCTs of all three agents $[39,44,46]$. Anakinra appears to be of greater benefit to the systemic, rather than the articular, features of sJIA when not used at disease onset/diagnosis [64,65]; this topic will be discussed further below. Anakinra was ineffective in a trial of children with pJIA [38].

\section{Abatacept}

Abatacept is a soluble fusion protein consisting of the Cytotoxic T cell Lymphocyte Antigen-4 fused with the Fc region of human IgG [66]. The rationale behind its use has been described [67]. Only one RCT involving abatacept in children with JIA has been published, with the study showing efficacy in children with polyarticularcourse JIA [35]. Fifty-seven of 190 (30\%) subjects enrolled in this study had previously received TNFi, and these patients appeared to demonstrate a less robust response, presumably reflecting a bias towards more recalcitrant disease.

\section{Tocilizumab}

IL-6 is another highly pro-inflammatory cytokine [68]; tocilizumab is a monoclonal antibody directed against the IL- 6 receptor. It is the only biologic to be evaluated with RCTs and found to be effective for both pJIA and sJIA. In children with sJIA, tocilizumab was effective in both the systemic as well as the articular symptoms of the disease [43]. Additionally, a RCT of children with pJIA showed substantial improvement [45].

\section{Rituximab}

Rituximab is a chimeric monoclonal antibody directed against the human CD20 receptor, which is present only on $B$ cells [69]. It has not been used much in children with JIA, perhaps out of a concern that it will only be effective in diseases with an identifiable antibody. Thus, data is limited to case reports and one case series, which have largely been positive [70-76]. These studies, though limited in numbers and not randomized, do suggest the concerns that rituximab will only be effective in patients with a positive RF may be unfounded, as subjects with multiple JIA categories have responded well.

\section{Safety of biologic therapy}

The RCTs of biologic therapies in children with JIA have for the most part not raised any significant safety concerns [32-46]. However, limitations of RCTs in the assessment of drug safety include the relatively low number of subjects enrolled and short trial duration, which limit the ability of these studies to detect rare events and long term side effects [77]. Since TNFi are the oldest class of engineered biologics and the most widely used [6], existing registries can provide ample real-world assessments of their safety, and these registries have indeed confirmed the safety of TNF inhibition in both the short and long terms [32-42,78-81]. For example, Giannini and colleagues followed 397 subjects over a three-year period who received etanercept either with or without MTX, reporting rates of SAEs that were similar to those seen in children taking MTX as mono-therapy [81].

Whether TNFi are associated with an increased risk of malignancy in children is unclear. A recent study showed that children treated with etanercept had a higher incidence of Hodgkin's lymphoma compared to the general population, as indicated by the Surveillance Epidemiology and End Results database [82]. However, the interpretation of this finding is clouded by the increased baseline incidence of malignancy among children with JIA [83,84]. Furthermore, a study of children with Medicaid insurance evaluated from years 2000 - 2005 showed no malignancies among 1,484 patients treated with TNFi, over nearly 3,000 person-years of therapy [83].

With respect to IL-1 inhibition, abatacept, tocilizumab, and rituximab, there is much less safety data, necessitating that the safety of these medicines either in other populations (e.g. adults with rheumatoid arthritis) or, in the case of rituximab, for other indications (e.g. children with idiopathic thrombocytopenic purpura), must be considered. None of the RCTs involving anakinra, canakinumab, and abatacept showed significant safety signals; likewise, the overall experience in adults with rheumatoid arthritis has shown anakinra and abatacept to be safe, with perhaps a decreased risk of serious adverse events compared even to TNFi [85]. One study addressed findings of pulmonary 
complications of interstitial lung disease and pulmonary hypertension in patients with sJIA, concluding that this was likely associated with underlying disease characteristics rather than its treatment in most cases [86]. Similarly, the limited experience in children with JIA has shown rituximab to be well-tolerated in this population, just as it was in a larger cohort of children with idiopathic thrombocytopenic purpura [87]. In contrast, pediatric studies involving tocilizumab have revealed several safety concerns, including elevated liver function tests, lymphopenia, neutropenia, gastrointestinal hemorrhage, and possibly an increased risk of serious infections $[37,43,88]$. Specifically, Yokota et al. (2008) reported "striking" elevations of liver function tests (alanine aminotransferase [ALT] of 676) in a child with Ebstein-Barr Virus infection along with a case of gastrointestinal hemorrhage in the double-blind phase, along with grade 2 elevations of ALT in 12/50 subjects during the 48-week open label extension phase [37]. Likewise, de Benedetti et al. (2012) reported ALT elevations above 2.5 times the upper limit of normal in 21 out of 112 tocilizumab-treated patients, along with neutrophil counts of less than $1 \times 10^{9}$ / liter in 17 patients and less than $0.5 \mathrm{x}$ $10^{9}$ in two patients. They also reported two serious infections among 75 tocilizumab-treated compared to none of 37 placebo-treated patients in the 12-week double blind phase [43]. Some of these findings have also been seen in adult studies [89]. Moreover, all of the biologics have been linked in case reports to rare but serious infections, including in the case of rituximab rare reports of progressive multifocal leukoencephalopathy [90,91]. Additionally, etanercept and chimeric antibodies administered intravenously, namely infliximab and rituximab, have been associated with anaphylactic reactions [34,92,93]. Finally, TNFi have been linked with additional rare AEs, including induction of autoimmune diseases such as lupus [94], psoriasis, cutaneous vasculitis, and multiple sclerosis [95] and rare infections such as tuberculosis and histoplasmosis [96]. Nevertheless, the overall benefit to side effect ratio of biologic agents used to treat JIA appears to be remarkably high.

\section{Treatment of JIA complications}

\section{Macrophage activation syndrome (MAS)}

MAS, a secondary form of hemophagocytic lymphohistiocytosis (HLH), arises from a pro-inflammatory cytokine storm, which is thought to result from a defect in CD8 $\mathrm{T}$ cell and/or natural killer cell cytolytic capacity [97]. MAS can lead to pancytopenia, coagulopathy, liver dysfunction, central nervous system dysfunction, and death if under-recognized or under-treated. Although MAS can be associated with hematologic malignancies or certain infections (particularly, members of the herpes virus family), it is commonly associated with sJIA [98]. MAS has also been reported among subjects treated with tocilizumab and IL-1 antagonists for sJIA [43,44,65]; this does not imply causality, although it does provide caution that even IL- 6 and IL-1 blockade may not always be protective against it. There is substantial clinical and laboratory overlap between features of MAS and of active sJIA [97], so reported effectiveness of anakinra in the management of MAS secondary to sJIA comes as little surprise $[99,100]$. Anakinra has also found a role in treating MAS associated with diseases other than sJIA, including idiopathic MAS [101,102]. None of the other biologics have so far found a place in the management of MAS but time will tell; among the traditional DMARDs, cyclosporine, which is otherwise rarely used to treat JIA, has long been considered standard of care in the treatment of MAS [103,104]. Combination therapy with high dose corticosteroids, cyclosporine, and anakinra is likely to replace more traditional and risky cytotoxic approaches [104] for treating many secondary forms of HLH and MAS [105].

\section{Uveitis}

Asymptomatic chronic uveitis is a frequent complication of JIA, occurring in $30 \%$ of children with ANA+ disease [106]. Children with ERA are at risk for the acute anterior uveitis characteristic of adults with SpA [107]; treatment of both types of uveitis are similar. Methotrexate appears to be the most widely used first-line agent in addition to topical CS, and its use may even prevent onset of uveitis [108]. Among the biologics, the TNFi have been the most widely used [109], although the monoclonal antibodies are more effective than etanercept [110]. To prevent steroid related side effects (e.g. cataracts, glaucoma) and to maintain disease remission, dose escalation to as high as $20 \mathrm{mg} / \mathrm{kg}$ of infliximab is occasionally required [51,111]. For patients who have failed therapy with both MTX and $\mathrm{TNFi}$, there is minimal data to guide subsequent management. There have been successful case reports with mycophenolate mofetil [112], abatacept [113-115], and rituximab $[116,117]$. With proper ophthalmologic screening and prompt therapy with steroid sparing MTX and biologic agents, the risk of blindness from JIA-associated uveitis has been dramatically reduced [118].

\section{Early aggressive therapy}

There may be a window of opportunity to most effectively treat chronic arthritis, and evidence is accumulating to support the benefits of early and aggressive therapy. The concept of early aggressive therapy is perhaps best illustrated in the case of sJIA. This disease appears to have two phases: a systemic phase characterized by fevers, elevated inflammatory markers, and rash; followed by an articular phase, characterized by predominance of arthritis [119]. Serum taken from children in the systemic phase induces a strong interleukin-1 signature in peripheral blood mononuclear cells obtained from healthy subjects [63], and 
therapy with IL-1 blockade is highly effective in newlydiagnosed patients $[64,120]$. In contrast, studies evaluating subjects with a wide range of disease duration, which generally includes many subjects in the articular phase of the illness, show mixed benefit from anakinra [121], possibly indicating changes in the underlying biology of the disease that could complicate therapy.

Two studies of children with pJIA also helped illustrate this concept. The first was a study of SSZ in 68 children with oligoarticular or polyarticular juvenile chronic arthritis conducted from 1992-1994 and published in 1997, the primary outcome being improvements in joint counts and other measures over a 24-week period. Most impressively, a 9-year follow-up study in which 61 participants were re-assessed by physical exam revealed improved joint counts and overall well-being among those initially assigned to SSZ, despite similar patterns of DMARD use following the conclusion of the actual trial [21]. More recently, in the Trial of Early Aggressive Therapy, children with PJIA were randomized to receive MTX versus MTX plus etanercept and a tapering dose of CS [42]. Although the study failed to meet its primary aim of statistically significant differences in the incidence of clinically inactive disease at six months, secondary analyses did reveal that regardless of treatment arm, the duration of disease prior to enrolment in the trial was inversely correlated with likelihood of obtaining inactive disease. Likewise, data from the German etanercept registry revealed that a positive predictor of response to etanercept was short disease duration prior to initiation of therapy [122].

Studies in adults indicate that a window of opportunity may also apply with respect to SpA, although in this case, the window may be much longer. Specifically, patients with advanced spinal lesions show progression of the structural changes despite therapy with TNFi [123]; however, recent data suggest that subjects with early spinal changes show regression of the lesions without new bone formation when treating with TNFi [124].

It is clear that the window of opportunity will vary widely both by underlying disease and by individual patient characteristics. Even in the absence of such a window, the benefits of obtaining rapid control of a potentially debilitating and painful medical condition that may also effect growth in young children, whose entire lives are ahead of them, are incontrovertible.

\section{Conclusions}

A generation ago, a diagnosis of chronic juvenile arthritis relegated children to a lifetime of pain, disability, and dsymorphology (the latter in no small part due to TMJ arthritis), with an increased risk of mortality as well observed in older studies [125]. Today, there are a multitude of treatment options, which taken together have allowed children with arthritis to experience normal growth and development. As more is learned about the etiopathogenesis of the different categories of JIA, it may become easier to target the right drug to the right child. For now, however, it is clear that most children with nonsystemic JIA respond well to TNFi and MTX, and that most children with sJIA respond well to IL-1 and IL-6 blockade. It is also clear that methotrexate and the biologic medicines are typically well-tolerated by children, and that early and aggressive therapy yields optimal outcomes.

\section{Abbreviations}

CS: Corticosteroids; DMARD: Disease-modifying anti-rheumatic drug; ERA: Enthesitis-related arthritis; HLH: Hemophagocytic lymphohistiocytosis; IA: Intra-articular; IL: Interleukin; JIA: Juvenile idiopathic arthritis; MAS: Macrophage activation syndrome; MTX: Methotrexate; NSAID: Nonsteroidal anti-inflammatory drug; OJA: Oligoarticular JIA; pJIA: Polyarticular JIA; psJIA: Psoriatic JIA; RA: Rheumatoid arthritis; RCT: Randomized controlled trial; RF: Rheumatoid factor; sJA: Systemic JIA; SpA: Spondyloarthritis; SSZ: Sulfasalazine; SQ: Subcutaneous; TMJ: Temporomandibular joint; TNFi: Tumor necrosis factor inhibitor.

\section{Competing interests}

Dr. Stoll has no conflicts of interest. Dr. Cron has consulted for $<\$ 5000$ each for Novartis, Genentech, and Swedish Orphan Biovitrum (producer of anakinra).

\section{Authors' contributions}

Both MLS and RQC were involved in the drafting and critical review of the manuscript and approve the final version.

\section{Authors' information}

MLS is Assistant Professor in the Department of Pediatrics, Division of Rheumatology, at the University of Alabama at Birmingham. RQC is Professor in the Department of Pediatrics, Division of Rheumatology, at the University of Alabama at Birmingham.

Received: 19 March 2014 Accepted: 10 April 2014 Published: 23 April 2014

\section{References}

1. Petty RE, Southwood TR, Manners P, Baum J, Glass DN, Goldenberg J, He X, Maldonado-Cocco J, Orozco-Alcala J, Prieur AM, Suarez-Almazor ME, Woo P: International League of Associations for Rheumatology classification of juvenile idiopathic arthritis: second revision, Edmonton, 2001. J Rheumatol 2004, 31(2):390-392.

2. Cron $R Q$, Weiser $P$, Beukelman $T$ : Juvenile idiopathic arthritis. In Clinical Immunology: Principles and Practice (4th edition). Edited by Rich RR, Fleisher TA, Shearer WT, Schroeder II HW, Frew AJ, and Weyand CM. London, England: Elsevier; 2013: 637-647.

3. Levinson JE, Wallace CA: Dismantling the pyramid. J Rheumatol Supp/ 1992, 33:6-10.

4. Foster HE, Marshall N, Myers A, Dunkley P, Griffiths ID: Outcome in adults with juvenile idiopathic arthritis: a quality of life study. Arthritis Rheum 2003, 48(3):767-775.

5. Beukelman T, Patkar NM, Saag KG, Tolleson-Rinehart S, Cron RQ, DeWitt EM, llowite NT, Kimura Y, Laxer RM, Lovell DJ: 2011 American College of Rheumatology recommendations for the treatment of juvenile idiopathic arthritis: initiation and safety monitoring of therapeutic agents for the treatment of arthritis and systemic features. Arthritis Care Res (Hoboken) 2011, 63(4):465-482.

6. Beukelman T, Ringold S, Davis TE, DeWitt EM, Pelajo CF, Weiss PF, Kimura Y: Disease-modifying antirheumatic drug use in the treatment of juvenile idiopathic arthritis: a cross-sectional analysis of the CARRA Registry. J Rheumatol 2012, 39(9):1867-1874.

7. Gotte AC: Intra-articular corticosteroids in the treatment of juvenile idiopathic arthritis: safety, efficacy, and features affecting outcome. A comprehensive review of the literature. Open Access Rheumatology Research and Reviews 2009, 1:37-49.

8. Zulian F, Martini G, Gobber D, Plebani M, Zacchello F, Manners P: Triamcinolone acetonide and hexacetonide intra-articular treatment of 
symmetrical joints in juvenile idiopathic arthritis: a double-blind trial. Rheumatology (Oxford) 2004, 43(10):1288-1291.

9. Stoll ML, Sharpe T, Beukelman T, Good J, Young D, Cron RQ: Risk factors for temporomandibular joint arthritis in children with juvenile idiopathic arthritis. J Rheumato/ 2012, 39(9):1880-1887

10. Arabshahi B, Cron RQ: Temporomandibular joint arthritis in juvenile idiopathic arthritis: the forgotten joint. Curr Opin Rheumatol 2006, 18(5):490-495.

11. Cron RQ, Sharma S, Sherry DD: Current treatment by United States and Canadian pediatric rheumatologists. J Rheumatol 1999, 26(9):2036-2038.

12. Giannini EH, Brewer EJ, Kuzmina N, Shaikov A, Maximov A, Vorontsov I, Fink CW, Newman AJ, Cassidy JT, Zemel LS: Methotrexate in resistant juvenile rheumatoid arthritis. Results of the U.S.A.-U.S.S.R. double-blind, placebo-controlled trial. The Pediatric Rheumatology Collaborative Study Group and The Cooperative Children's Study Group. N Engl J Med 1992, 326(16):1043-1049.

13. Ramanathan A, Srinivasalu H, Colbert RA: Update on juvenile spondyloarthritis. Rheum Dis Clin North Am 2013, 39(4):767-788.

14. van der Heijde D, Sieper J, Maksymowych WP, Dougados M, Burgos-Vargas R, Landewe R, Rudwaleit M, Braun J: 2010 Update of the international ASAS recommendations for the use of anti-TNF agents in patients with axial spondyloarthritis. Ann Rheum Dis 2011, 70(6):905-908.

15. Klein A, Kaul I, Foeldvari I, Ganser G, Urban A, Horneff G: Efficacy and safety of oral and parenteral methotrexate therapy in children with juvenile idiopathic arthritis: an observational study with patients from the German Methotrexate Registry. Arthritis Care Res (Hoboken) 2012, 64(9):1349-1356.

16. Tukova J, Chladek J, Nemcova D, Chladkova J, Dolezalova P: Methotrexate bioavailability after oral and subcutaneous dministration in children with juvenile idiopathic arthritis. Clin Exp Rheumatol 2009, 27(6):1047-1053.

17. Alsufyani K, Ortiz-Alvarez O, Cabral DA, Tucker LB, Petty RE, Malleson PN: The role of subcutaneous administration of methotrexate in children with juvenile idiopathic arthritis who have failed oral methotrexate. J Rheumatol 2004, 31(1):179-182.

18. Ruperto N, Murray KJ, Gerloni V, Wulffraat N, de Oliveira SK, Falcini F, Dolezalova P, Alessio M, Burgos-Vargas R, Corona F, Vesely R, Foster H, Davidson J, Zulian F, Asplin L, Baildam E, Consuegra JG, Ozdogan H, Saurenmann $R$, Joos $R$, Pistorio A, Woo $P$, Martini A: A randomized trial of parenteral methotrexate comparing an intermediate dose with a higher dose in children with juvenile idiopathic arthritis who failed to respond to standard doses of methotrexate. Arthritis Rheum 2004, 50(7):2191-2201.

19. Becker ML, Rose $C D$, Cron RQ, Sherry DD, Bilker WB, Lautenbach $E$ Effectiveness and toxicity of methotrexate in juvenile idiopathic arthritis: comparison of 2 initial dosing regimens. J Rheumato/ 2010, 37(4):870-875.

20. van Rossum MA, Fiselier TJ, Franssen MJ, Zwinderman AH, ten Cate R, van Suijlekom-Smit LW, van Luijk WH, van Soesbergen RM, Wulffraat NM, Oostveen JC, Kuis W, Dijkstra PF, Can Ede CF, Dijksmans BA: Sulfasalazine in the treatment of juvenile chronic arthritis: a randomized, double-blind, placebo-controlled, multicenter study. Dutch Juvenile Chronic Arthritis Study Group. Arthritis Rheum 1998, 41(5):808-816.

21. van Rossum MA, van Soesbergen RM, Boers M, Zwinderman $A H$, Fiselier TJ, Franssen MJ, ten Cate R, van Suijlekom-Smit LW, Wulffraat NM, van Luijk WH, Oostveen JC, Kuis W, Dijkmans BA: Long-term outcome of juvenile idiopathic arthritis following a placebo-controlled trial: sustained benefits of early sulfasalazine treatment. Ann Rheum Dis 2007, 66(11):1518-1524.

22. Ansell BM, Hall MA, Loftus JK, Woo P, Neumann V, Harvey A, Sills JA, Swinson $D$, Insley J, Amos R, et al: A multicentre pilot study of sulphasalazine in juvenile chronic arthritis. Clin Exp Rheumatol 1991, 9(2):201-203.

23. Prieur AM, Quartier P: Comparative tolerability of treatments for juvenile idiopathic arthritis. BioDrugs 2000, 14(3):159-183.

24. Jung JH, Jun JB, Yoo DH, Kim TH, Jung SS, Lee IH, Bae SC, Kim SY: High toxicity of sulfasalazine in adult-onset Still's disease. Clin Exp Rheumatol 2000, 18(2):245-248.

25. Hertzberger-ten Cate $\mathrm{R}$, Cats A: Toxicity of sulfasalazine in systemic juvenile chronic arthritis. Clin Exp Rheumatol 1991, 9(1):85-88.

26. Silverman E, Mouy R, Spiegel L, Jung LK, Saurenmann RK, Lahdenne P, Horneff G, Calvo I, Szer IS, Simpson K, Stewart JA, Strand V: Leflunomide or methotrexate for juvenile rheumatoid arthritis. N Engl J Med 2005, 352(16):1655-1666

27. Ruperto N, Ravelli A, Castell E, Gerloni V, Haefner R, Malattia C, KanakoudiTsakalidou F, Nielsen S, Bohnsack J, Gibbas D, Rennebohm R, Voygioyka O, Balogh Z, Lepore L, Macejkova E, Wulffraat N, Oliveira S, Russo R, Buoncompagn A, Hilário MO, Alpigiani MG, Passo M, Lovell DJ, Merino R, Martini A, Giannini EH:
Cyclosporine A in juvenile idiopathic arthritis. Results of the PRCSG/ PRINTO phase IV post marketing surveillance study. Clin Exp Rheumatol 2006, 24(5):599-605

28. Gerloni V, Cimaz R, Gattinara M, Arnoldi C, Pontikaki I, Fantini F: Efficacy and safety profile of cyclosporin $A$ in the treatment of juvenile chronic (idiopathic) arthritis. Results of a 10-year prospective study. Rheumatology (Oxford) 2001, 40(8):907-913.

29. Giannini EH, Cassidy JT, Brewer EJ, Shaikov A, Maximov A, Kuzmina N: Comparative efficacy and safety of advanced drug therapy in children with juvenile rheumatoid arthritis. Semin Arthritis Rheum 1993, 23(1):34-46.

30. Brewer EJ, Giannini EH, Kuzmina N, Alekseev L: Penicillamine and hydroxychloroquine in the treatment of severe juvenile rheumatoid arthritis. Results of the U.S.A.-U.S.S.R. double-blind placebo-controlled trial. N Engl J Med 1986, 314(20):1269-1276.

31. Kvien TK, Hoyeraal HM, Sandstad B: Azathioprine versus placebo in patients with juvenile rheumatoid arthritis: a single center double blind comparative study. J Rheumatol 1986, 13(1):118-123.

32. Lovell DJ, Giannini EH, Reiff A, Cawkwell GD, Silverman ED, Nocton JJ, Stein LD, Gedalia A, llowite NT, Wallace CA, Whitmore J, Finck BK: Etanercept in children with polyarticular juvenile rheumatoid arthritis. Pediatric Rheumatology Collaborative Study Group. N Engl J Med 2000, 342(11):763-769.

33. Smith JA, Thompson DJ, Whitcup SM, Suhler E, Clarke G, Smith S, Robinson M, Kim J, Barron KS: A randomized, placebo-controlled, double-masked clinical trial of etanercept for the treatment of uveitis associated with juvenile idiopathic arthritis. Arthritis Rheum 2005, 53(1):18-23.

34. Ruperto N, Lovell DJ, Cuttica R, Wilkinson N, Woo P, Espada G, Wouters C, Silverman ED, Balogh Z, Henrickson M, Apaz MT, Baildam E, Fasth A, Gerloni V, Lahdenne P, Prieur AM, Ravelli A, Saurenmann RK, Gamir ML, Wulffraat N, Marodi L, Petty RE, Joos R, Zulian F, McCurdy D, Myones BL, Nagy K, Reuman P, Szer I, Travers S, et al: A randomized, placebocontrolled trial of infliximab plus methotrexate for the treatment of polyarticular-course juvenile rheumatoid arthritis. Arthritis Rheum 2007 56(9):3096-3106.

35. Ruperto N, Lovell DJ, Quartier P, Paz E, Rubio-Perez N, Silva CA, AbudMendoza C, Burgos-Vargas R, Gerloni V, Melo-Gomes JA, Saad-Magalhães C, Sztajnbok F, Goldenstein-Schainberg C, Scheinberg M, Penades IC, Fischbach M, Orozco J, Hashkes PJ, Hom C, Jung L, Lepore L, Oliveira S, Wallace CA, Sigal LH, Block AJ, Covucci A, Martini A, Giannini EH: Abatacept in children with juvenile idiopathic arthritis: a randomised, double-blind, placebo-controlled withdrawal trial. Lancet 2008, 372(9636):383-391.

36. Lovell DJ, Ruperto N, Goodman S, Reiff A, Jung L, Jarosova K, Nemcova D, Mouy R, Sandborg C, Bohnsack J, Elewaut D, Foeldvari I, Gerloni V, Rovensky J, Minden K, Vehe RK, Weiner LW, Horneff G, Huppertz HI, Olson NY, Medich JR, Carcereri-De-Prati R, Mcllraith MJ, Giannini EH, Martini A: Adalimumab with or without methotrexate in juvenile rheumatoid arthritis. N Engl J Med 2008, 359(8):810-820.

37. Yokota S, Imagawa T, Mori M, Miyamae T, Aihara Y, Takei S, Iwata N, Umebayashi H, Murata T, Miyoshi M, Tomiita M, Nishimoto N, Kishimoto T: Efficacy and safety of tocilizumab in patients with systemic-onset juvenile idiopathic arthritis: a randomised, double-blind, placebocontrolled, withdrawal phase III trial. Lancet 2008, 371(9617):998-1006.

38. Ilowite N, Porras O, Reiff A, Rudge S, Punaro M, Martin A, Allen R, Harville T, Sun YN, Bevirt T, Aras G, Appleton B: Anakinra in the treatment of polyarticularcourse juvenile rheumatoid arthritis: safety and preliminary efficacy results of a randomized multicenter study. Clin Rheumato/ 2009, 28(2):129-137.

39. Quartier P, Allantaz F, Cimaz R, Pillet P, Messiaen C, Bardin C, Bossuyt X Boutten A, Bienvenu J, Duquesne A, Richer O, Chaussabel D, Mogenet A, Banchereau J, Treluyer JM, Landais P, Pascual V: A multicentre, randomised, double-blind, placebo-controlled trial with the interleukin-1 receptor antagonist anakinra in patients with systemic-onset juvenile idiopathic arthritis (ANAJIS trial). Ann Rheum Dis 2011, 70(5):747-754.

40. Tynjala P, Vahasalo P, Tarkiainen M, Kroger L, Aalto K, Malin M, Putto-Laurila A, Honkanen $V$, Lahdenne P: Aggressive combination drug therapy in very early polyarticular juvenile idiopathic arthritis (ACUTE-JIA): a multicentre randomised open-label clinical trial. Ann Rheum Dis 2011, 70(9):1605-1612.

41. Horneff G, Fitter S, Foeldvari I, Minden K, Kuemmerle-Deschner J, Tzaribacev N, Thon A, Borte M, Ganser G, Trauzeddel R, Huppertz HI: Double blind, Placebocontrolled randomized trial with Adalimumab for Treatment of Juvenile onset Ankylosing Spondylitis (JoAS): significant short term improvement. Arthritis Res Ther 2012, 14(5):R230. 
42. Wallace CA, Giannini EH, Spalding SJ, Hashkes PJ, O'Neil KM, Zeft AS, Szer IS, Ringold S, Brunner HI, Schanberg LE, Sundel RP, Milojevic D, Punaro MG, Chira P, Gottlieb BS, Higgins GC, Ilowite NT, Kimura Y, Hamilton S, Johnson A, Huang B, Lovell DJ: Trial of early aggressive therapy in polyarticular juvenile idiopathic arthritis. Arthritis Rheum 2012, 64(6):2012-2021.

43. De Benedetti F, Brunner HI, Ruperto N, Kenwright A, Wright S, Calvo I, Cuttica R, Ravelli A, Schneider R, Woo P, Wouters C, Xavier R, Zemel L, Baildam E, Burgos-Vargas R, Dolezalova P, Garay SM, Merino R, Joos R, Grom A, Wulffraat N, Zuber Z, Zulian F, Lovell D, Martini A: Randomized Trial of Tocilizumab in Systemic Juvenile Idiopathic Arthritis. N Engl J Med 2012, 367(25):2385-2395.

44. Ruperto N, Brunner HI, Quartier P, Constantin T, Wulffraat N, Horneff G, Brik R, McCann L, Kasapcopur O, Rutkowska-Sak L, Schneider R, Berkun Y, Calvo I, Erguven M, Goffin L, Hofer M, Kallinich T, Oliveira SK, Uziel Y, Viola S, Nistala K, Wouters C, Cimaz R, Ferrandiz MA, Flato B, Gamir ML, Kone-Paut I, Grom A, Magnusson B, Ozen S, et al: Two Randomized Trials of Canakinumab in Systemic Juvenile Idiopathic Arthritis. N Engl J Med 2012, 367(25):2396-2406.

45. Brunner H, Ruperto N, Zuber Z, Keane C, Harari O, Kenwright A, Cuttica RJ, Keltsev V, Xavier R, Penades IC, Nikishina I, Rubio-Perez N, Alekseeva E, Chasnyk V, Horneff G, Opoka-Winiarska V, Quartier P, Silva CA, Silverman ED, Spindler A, Lovell DJ, Martini A, De Benedetti F: Efficacy of safety of tocilizumab in patients with polyarticular juvenile idipoathic arthritis: data from a phase 3 trial [abstract]. Arthritis Rheum 2012, 64(10):S682.

46. Lovell DJ, Giannini EH, Reiff AO, Kimura Y, Li S, Hashkes PJ, Wallace CA, Onel KB, Foell D, Wu R, Biedermann S, Hamilton JD, Radin AR: Long-term safety and efficacy of rilonacept in patients with systemic juvenile idiopathic arthritis. Arthritis Rheum 2013, 65(9):2486-2496.

47. Hopkins SJ, Meager A: Cytokines in synovial fluid: II. The presence of tumour necrosis factor and interferon. Clin Exp Immunol 1988, 73(1):88-92.

48. Eberhard BA, Laxer RM, Andersson U, Silverman ED: Local synthesis of both macrophage and T cell cytokines by synovial fluid cells from children with juvenile rheumatoid arthritis. Clin Exp Immunol 1994, 96(2):260-266.

49. Zhou $\mathrm{H}$ : Clinical pharmacokinetics of etanercept: a fully humanized soluble recombinant tumor necrosis factor receptor fusion protein. $J$ Clin Pharmacol 2005, 45(5):490-497.

50. Feldmann M, Brennan FM, Williams RO, Woody JN, Maini RN: The transfer of a laboratory based hypothesis to a clinically useful therapy: the development of anti-TNF therapy of rheumatoid arthritis. Best Pract Res Clin Rheumatol 2004, 18(1):59-80

51. Tambralli A, Beukelman T, Weiser P, Atkinson TP, Cron RQ, Stoll ML: High doses of infliximab in the management of juvenile idiopathic arthritis J Rheumatol 2013, 40(10):1749-1755.

52. Otten MH, Prince FH, Ten Cate $R$, van Rossum MA, Twilt M, Hoppenreijs EP Koopman-Keemink Y, Oranje AP, der Spek FB d W-V, Gorter SL, Armbrust W, Dolman KM, Wulffraat NM, van Suijlekom-Smit LW: Tumour necrosis factor (TNF)-blocking agents in juvenile psoriatic arthritis: are they effective? Ann Rheum Dis 2011, 70(2):337-340.

53. Henrickson M, Reiff A: Prolonged efficacy of etanercept in refractory enthesitis-related arthritis. J Rheumatol 2004, 31(10):2055-2061.

54. Tse SM, Burgos-Vargas R, Laxer RM: Anti-tumor necrosis factor alpha blockade in the treatment of juvenile spondylarthropathy. Arthritis Rheum 2005, 52(7):2103-2108.

55. Horneff G, Burgos-Vargas R, Constantin T, Foeldvari I, Vojinovic J, Chasnyk VG, Dehoorne J, Panaviene V, Susic G, Stanevica V, Kobusinska K, Zuber Z, Mouy R, Rumba-Rozenfelde I, Breda L, Dolezalova P, Job-Deslandre C, Wulffraat N, Alvarez D, Zang C, Wajdula J, Woodworth D, Vlahos B, Martini A, Ruperto N: Efficacy and safety of open-label etanercept on extended oligoarticular juvenile idiopathic arthritis, enthesitis-related arthritis and psoriatic arthritis: part 1 (week 12) of the CLIPPER study. Ann Rheum Dis. ePub.

56. Quartier P, Taupin P, Bourdeaut F, Lemelle I, Pillet P, Bost M, Sibilia J, Kone-Paut I, Gandon-Laloum S, LeBideau M, Bader-Meunier B, Mouy R, Debré M, Landais $P$, Prieur AM: Efficacy of etanercept for the treatment of juvenile idiopathic arthritis according to the onset type. Arthritis Rheum 2003, 48(4):1093-1101.

57. Horneff G, Schmeling H, Biedermann T, Foeldvari I, Ganser G, Girschick HJ, Hospach T, Huppertz HI, Keitzer R, Küster RM, Michels H, Moebius D, Rogalski B, Thon A: The German etanercept registry for treatment of juvenile idiopathic arthritis. Ann Rheum Dis 2004, 63(12):1638-1644.

58. Horneff G, De Bock F, Foeldvari I, Girschick HJ, Michels H, Moebius D, Schmeling H: Safety and efficacy of combination of etanercept and methotrexate compared to treatment with etanercept only in patients with juvenile idiopathic arthritis (JIA): preliminary data from the German JIA Registry. Ann Rheum Dis 2009, 68(4):519-525.
59. Weinblatt M, Combe B, Covucci A, Aranda R, Becker JC, Keystone E: Safety of the selective costimulation modulator abatacept in rheumatoid arthritis patients receiving background biologic and nonbiologic disease-modifying antirheumatic drugs: A one-year randomized, placebo-controlled study. Arthritis Rheum 2006, 54(9):2807-2816.

60. Weinblatt M, Schiff M, Goldman A, Kremer J, Luggen M, Li T, Chen D, Becker JC Selective costimulation modulation using abatacept in patients with active rheumatoid arthritis while receiving etanercept: a randomised clinical trial. Ann Rheum Dis 2007, 66(2):228-234.

61. Dinarello CA, Simon A, van der Meer JW: Treating inflammation by blocking interleukin-1 in a broad spectrum of diseases. Nat Rev Drug Discov 2012, 11(8):633-652.

62. Verbsky JW, White AJ: Effective use of the recombinant interleukin 1 receptor antagonist anakinra in therapy resistant systemic onset juvenile rheumatoid arthritis. J Rheumato/ 2004, 31(10):2071-2075.

63. Pascual V, Allantaz F, Arce E, Punaro M, Banchereau J: Role of interleukin-1 (IL-1) in the pathogenesis of systemic onset juvenile idiopathic arthritis and clinical response to IL-1 blockade. J Exp Med 2005, 201(9):1479-1486.

64. Nigrovic PA, Mannion M, Prince FH, Zeft A, Rabinovich CE, van Rossum MA, Cortis E, Pardeo M, Nigrovic PA, Mannion M, Prince FH, Zeft A, Rabinovich CE, van Rossum MA, Cortis E, Pardeo M, Miettunen PM, Janow G, Birmingham J, Eggebeen A, Janssen E, Shulman Al, Son MB, Hong S, Jones K, llowite NT, Cron RQ, Higgins GC: Anakinra as first-line disease-modifying therapy in systemic juvenile idiopathic arthritis: report of forty-six patients from an international multicenter series. Arthritis Rheum 2011, 63(2):545-555.

65. Zeft A, Hollister R, LaFleur B, Sampath P, Soep J, McNally B, Kunkel G, Schlesinger M, Bohnsack J: Anakinra for systemic juvenile arthritis: the Rocky Mountain experience. J Clin Rheumatol 2009, 15(4):161-164.

66. Linsley PS, Brady W, Urnes M, Grosmaire LS, Damle NK, Ledbetter JA: CTLA4 is a second receptor for the B cell activation antigen B7. J Exp Med 1991, 174(3):561-569.

67. Cron $\mathrm{RQ}:$ A signal achievement in the treatment of arthritis. Arthritis Rheum 2005, 52(8):2229-2232.

68. Ohsugi Y: Recent advances in immunopathophysiology of interleukin-6: an innovative therapeutic drug, tocilizumab (recombinant humanized anti-human interleukin- 6 receptor antibody), unveils the mysterious etiology of immune-mediated inflammatory diseases. Biol Pharm Bull 2007, 30(11):2001-2006.

69. Townsend MJ, Monroe JG, Chan AC: B-cell targeted therapies in human autoimmune diseases: an updated perspective. Immunol Rev 2010, 237(1):264-283

70. Feito JG, Pereda CA: Rituximab therapy produced rapid and sustained clinical improvement in a patient with systemic onset juvenile idiopathic arthritis refractory to TNF alpha antagonists. J Clin Rheumatol 2009, 15(7):363-365

71. Jansson AF, Sengler C, Kuemmerle-Deschner J, Gruhn B, Kranz AB, Lehmann H, Kleinert D, Pape L, Girschick HJ, Foeldvari I, Haffner D, Haas JP, Moebius D, Foell D, Peitz J, Grote V: B cell depletion for autoimmune diseases in paediatric patients. Clin Rheumatol 2011, 30(1):87-97.

72. El-Hallak M, Binstadt BA, Leichtner AM, Bennett CM, Neufeld EJ, Fuhlbrigge RC, Zurakowski D, Sundel RP: Clinical effects and safety of rituximab for treatment of refractory pediatric autoimmune diseases. J Pediatr 2007, 150(4):376-382

73. Narvaez J, Diaz-Torne C, Juanola X, Geli C, Llobet JM, Nolla JM, Diaz-Lopez C: Rituximab therapy for refractory systemic-onset juvenile idiopathic arthritis. Ann Rheum Dis 2009, 68(4):607-608.

74. Kasher-Meron M, Uziel Y, Amital H: Successful treatment with B-cell depleting therapy for refractory systemic onset juvenile idiopathic arthritis: a case report. Rheumatology (Oxford) 2009, 48(4):445-446.

75. Kuek A, Hazleman BL, Gaston JH, Ostor AJ: Successful treatment of refractory polyarticular juvenile idiopathic arthritis with rituximab. Rheumatology (Oxford) 2006, 45(11):1448-1449.

76. Alexeeva El, Valieva SI, Bzarova TM, Semikina EL, Isaeva KB, Lisitsyn AO, Denisova RV, Chistyakova EG: Efficacy and safety of repeat courses of rituximab treatment in patients with severe refractory juvenile idiopathic arthritis. Clin Rheumatol 2011, 30(9):1163-1172.

77. Pincus T, Stein CM: Why randomized controlled clinical trials do not depict accurately long-term outcomes in rheumatoid arthritis: some explanations and suggestions for future studies. Clin Exp Rheumatol 1997, 15(Suppl 17):S27-S38. 
78. Zuber Z, Rutkowska-Sak L, Postepski J, Dobrzyniecka B, Opoka-Winiarska V, Kobusinska K, Gietka P, Osinska V, Turowska-Heydel D, Szczygielska I, Kolodziejczyk B, Swiatek-Baczkowska A, Gazda A, Wiland P, Tlustochowicz W, Tuszkiewicz-Misztal E: Etanercept treatment in juvenile idiopathic arthritis: the Polish registry. Med Sci Monit 2011, 17(12):SR35-SR42.

79. Sevcic K, Orban I, Brodszky V, Bazso A, Balogh Z, Poor G, Kiss E: Experiences with tumour necrosis factor-\{alpha\} inhibitors in patients with juvenile idiopathic arthritis: Hungarian data from the National Institute of Rheumatology and Physiotherapy Registry. Rheumatology (Oxford) 2011, 50(7):1337-1340.

80. Prince FH, Twilt M, ten Cate R, van Rossum MA, Armbrust W, Hoppenreijs EP, van Santen-Hoeufft M, Koopman-Keemink Y, Wulffraat NM, van Suijlekom-Smit LW: Long-term follow-up on effectiveness and safety of etanercept in juvenile idiopathic arthritis: the Dutch national register. Ann Rheum Dis 2009, 68(5):635-641.

81. Giannini EH, llowite NT, Lovell DJ, Wallace CA, Rabinovich CE, Reiff A, Higgins G, Gottlieb B, Singer NG, Chon Y, Lin SL, Baumgartner SW: Long-term safety and effectiveness of etanercept in children with selected categories of juvenile idiopathic arthritis. Arthritis Rheum 2009, 60(9):2794-2804.

82. Hooper M, Wenkert D, Bitman B, Dias VC, Bartley Y: Malignancies in children and young adults on etanercept: summary of cases from clinical trials and post marketing reports. Pediatr Rheumatol Online J 2013, 11(1):35.

83. Beukelman T, Haynes K, Curtis JR, Xie F, Chen L, Bemrich-Stolz CJ, Delzell E, Saag KG, Solomon DH, Lewis JD: Rates of malignancy associated with juvenile idiopathic arthritis and its treatment. Arthritis Rheum 2012, 64(4):1263-1271.

84. Simard JF, Neovius M, Hagelberg S, Askling J: Juvenile idiopathic arthritis and risk of cancer: a nationwide cohort study. Arthritis Rheum 2010, 62(12):3776-3782.

85. Singh JA, Wells GA, Christensen R, Tanjong Ghogomu E, Maxwell L, Macdonald JK, Filippini G, Skoetz N, Francis D, Lopes LC, Guyatt GH, Schmitt J, La Mantia L, Weberschock T, Roos JF, Siebert H, Hershan S, Lunn MP, Tugwell P, Buchbinder R: Adverse effects of biologics: a network meta-analysis and Cochrane overview. Cochrane Database Syst Rev 2011 (2). CD008794.

86. Kimura Y, Weiss JE, Haroldson KL, Lee T, Punaro M, Oliveira S, Rabinovich E, Riebschleger M, Antón J, Blier PR, Gerloni V, Hazen MM, Kessler E, Onel K, Passo MH, Rennebohm RM, Wallace CA, Woo P, Wulffraat N: Pulmonary hypertension and other potentially fatal pulmonary complications in systemic juvenile idiopathic arthritis. Arthritis Care Res (Hoboken) 2013, 65(5):745-752.

87. Liang $Y$, Zhang L, Gao J, Hu D, Ai Y: Rituximab for children with immune thrombocytopenia: a systematic review. PLoS One 2012, 7(5):e36698.

88. Woo P, Wilkinson N, Prieur AM, Southwood T, Leone V, Livermore P, Wythe $\mathrm{H}$, Thomson D, Kishimoto T: Open label phase II trial of single, ascending doses of MRA in Caucasian children with severe systemic juvenile idiopathic arthritis: proof of principle of the efficacy of IL-6 receptor blockade in this type of arthritis and demonstration of prolonged clinical improvement. Arthritis Res Ther 2005, 7(6):R1281-R1288

89. Navarro G, Taroumian S, Barroso N, Duan L, Furst D: Tocilizumab in rheumatoid arthritis: A meta-analysis of efficacy and selected clinical conundrums. Semin Arthritis Rheum 2014, 43(4):458-469.

90. Stoll ML, Gotte AC: Biological therapies for the treatment of juvenile idiopathic arthritis: Lessons from the adult and pediatric experiences. Biologics 2008, 2(2):229-252.

91. Molloy ES, Calabrese LH: Progressive multifocal leukoencephalopathy associated with immunosuppressive therapy in rheumatic diseases: evolving role of biologic therapies. Arthritis Rheum 2012, 64(9):3043-3051.

92. Kimby E: Tolerability and safety of rituximab (MabThera). Cancer Treat Rev 2005, 31(6):456-473.

93. Crayne CB, Gerhold K, Cron RQ: Anaphylaxis to etanercept in two children with juvenile idiopathic arthritis. J Clin Rheumatol 2013, 19(3):129-131.

94. Williams EL, Gadola S, Edwards CJ: Anti-TNF-induced lupus. Rheumatology (Oxford) 2009, 48(7):716-720.

95. Perez-Alvarez R, Perez-de-Lis M, Ramos-Casals M: Biologics-induced autoimmune diseases. Curr Opin Rheumatol 2013, 25(1):56-64.

96. Rychly DJ, DiPiro JT: Infections associated with tumor necrosis factoralpha antagonists. Pharmacotherapy 2005, 25(9):1181-1192.

97. Ravelli A, Grom AA, Behrens EM, Cron RQ: Macrophage activation syndrome as part of systemic juvenile idiopathic arthritis: diagnosis, genetics, pathophysiology and treatment. Genes Immun 2012, 13(4):289-298.

98. Behrens EM, Beukelman T, Paessler M, Cron RQ: Occult macrophage activation syndrome in patients with systemic juvenile idiopathic arthritis. J Rheumatol 2007, 34(5):1133-1138.
99. Kelly A, Ramanan AV: A case of macrophage activation syndrome successfully treated with anakinra. Nat Clin Pract Rheumatol 2008, 4(11):615-620.

100. Bruck N, Suttorp M, Kabus M, Heubner G, Gahr M, Pessler F: Rapid and sustained remission of systemic juvenile idiopathic arthritis-associated macrophage activation syndrome through treatment with anakinra and corticosteroids. J Clin Rheumatol 2011, 17(1):23-27.

101. Miettunen PM, Narendran A, Jayanthan A, Behrens EM, Cron RQ: Successful treatment of severe paediatric rheumatic disease-associated macrophage activation syndrome with interleukin-1 inhibition following conventional immunosuppressive therapy: case series with 12 patients. Rheumatology (Oxford) 2011, 50(2):417-419.

102. Rajasekaran S, Kruse K, Kovey K, Davis AT, Hassan NE, Ndika AN, Zuiderveen S, Birmingham J: Therapeutic Role of Anakinra, an Interleukin-1 Receptor Antagonist, in the Management of Secondary Hemophagocytic Lymphohistiocytosis/Sepsis/Multiple Organ Dysfunction/Macrophage Activating Syndrome in Critically III Children. Pediatr Crit Care Med. ePub.

103. Mouy R, Stephan JL, Pillet P, Haddad E, Hubert P, Prieur AM: Efficacy of cyclosporine $A$ in the treatment of macrophage activation syndrome in juvenile arthritis: report of five cases. J Pediatr 1996, 129(5):750-754.

104. Henter Jl, Horne A, Arico M, Egeler RM, Filipovich AH, Imashuku S, Ladisch S, McClain K, Webb D, Winiarski J, Janka G: HLH-2004: Diagnostic and therapeutic guidelines for hemophagocytic lymphohistiocytosis. Pediatr Blood Cancer 2007, 48(2):124-131.

105. Canna SW, Behrens EM: Not all hemophagocytes are created equally: appreciating the heterogeneity of the hemophagocytic syndromes. Curr Opin Rheumatol 2012, 24(1):113-118.

106. Qian Y, Acharya NR: Juvenile idiopathic arthritis-associated uveitis. Curr Opin Ophthalmol 2010, 21(6):468-472.

107. Stoll ML, Bhore R, Dempsey-Robertson M, Punaro M: Spondyloarthritis in a pediatric population: risk factors for sacroiliitis. J Rheumatol 2010, 37(11):2402-2408.

108. Papadopoulou C, Kostik M, Bohm M, Nieto-Gonzalez JC, GonzalezFernandez MI, Pistorio A, Martini A, Ravelli A: Methotrexate therapy may prevent the onset of uveitis in juvenile idiopathic arthritis. J Pediatr 2013, 163(3):879-884.

109. Imrie FR, Dick AD: Biologics in the treatment of uveitis. Curr Opin Ophthalmol 2007, 18(6):481-486.

110. Foeldvari I, Nielsen S, Kummerle-Deschner J, Espada G, Horneff G, Bica B, Olivieri AN, Wierk A, Saurenmann RK: Tumor necrosis factor-alpha blocker in treatment of juvenile idiopathic arthritis-associated uveitis refractory to second-line agents: results of a multinational survey. J Rheumatol 2007, 34(5):1146-1150

111. Sukumaran S, Marzan K, Shaham B, Reiff A: High dose infliximab in the treatment of refractory uveitis: does dose matter? ISRN Rheumatol 2012, 2012:765380.

112. Sobrin L, Christen W, Foster CS: Mycophenolate mofetil after methotrexate failure or intolerance in the treatment of scleritis and uveitis. Ophthalmology 2008, 115(8):1416-1421. 1421 e1.

113. Kenawy N, Cleary G, Mewar D, Beare N, Chandna A, Pearce I: Abatacept: a potential therapy in refractory cases of juvenile idiopathic arthritisassociated uveitis. Graefes Arch Clin Exp Ophthalmol 2011, 249(2):297-300

114. Zulian F, Balzarin M, Falcini F, Martini G, Alessio M, Cimaz R, Cimino L, Zannin ME: Abatacept for severe anti-tumor necrosis factor alpha refractory juvenile idiopathic arthritis-related uveitis. Arthritis Care Res (Hoboken) 2010, 62(6):821-825.

115. Angeles-Han S, Flynn T, Lehman T: Abatacept for refractory juvenile idiopathic arthritis-associated uveitis- a case report. J Rheumatol 2008, 35(9):1897-1898

116. Heiligenhaus A, Miserocchi E, Heinz C, Gerloni V, Kotaniemi K: Treatment of severe uveitis associated with juvenile idiopathic arthritis with anti-CD20 monoclonal antibody (rituximab). Rheumatology (Oxford) 2011, 50(8):1390-1394.

117. Miserocchi E, Pontikaki I, Modorati G, Gattinara M, Meroni PL, Gerloni V: Anti-CD 20 monoclonal antibody (rituximab) treatment for inflammatory ocular diseases. Autoimmun Rev 2011, 11(1):35-39.

118. Heiligenhaus A, Heinz C, Edelsten C, Kotaniemi K, Minden K: Review for disease of the year: epidemiology of juvenile idiopathic arthritis and its associated uveitis: the probable risk factors. Ocul Immunol Inflamm 2013 21(3):180-191

119. Martini A: Systemic juvenile idiopathic arthritis. Autoimmun Rev 2012, 12(1):56-59

120. Vastert SJ, de Jager W, Noordman BJ, Holzinger D, Kuis W, Prakken BJ, Wulffraat NM: Effectiveness of first line use of recombinant IL-1RA 
treatment in steroid naïve systemic juvenile idiopathic arthritis: Results of a prospective cohort study. Arthritis Rheum. ePub.

121. Gattorno M, Piccini A, Lasiglie D, Tassi S, Brisca G, Carta S, Delfino L, Ferlito F, Pelagatti MA, Caroli F, Buoncompagni A, Viola S, Loy A, Sironi M, Vecchi A,

Ravelli A, Martini A, Rubartelli A: The pattern of response to anti-interleukin-1 treatment distinguishes two subsets of patients with systemic-onset juvenile idiopathic arthritis. Arthritis Rheum 2008, 58(5):1505-1515.

122. Geikowski T, Becker I, Horneff G: Predictors of response to etanercept in polyarticular-course juvenile idiopathic arthritis. Rheumatol. ePub.

123. van der Heijde D, Salonen D, Weissman BN, Landewe R, Maksymowych WP, Kupper H, Ballal S, Gibson E, Wong R: Assessment of radiographic progression in the spines of patients with ankylosing spondylitis treated with adalimumab for up to 2 years. Arthritis Res Ther 2009, 11(4):R127.

124. Maksymowych WP, Morency N, Conner-Spady B, Lambert RG: Suppression of inflammation and effects on new bone formation in ankylosing spondylitis: evidence for a window of opportunity in disease modification. Ann Rheum Dis 2013, 72(1):23-28.

125. Hashkes PJ, Wright BM, Lauer MS, Worley SE, Tang AS, Roettcher PA, Bowyer SL: Mortality outcomes in pediatric rheumatology in the US. Arthritis Rheum 2010 62(2):599-608.

doi:10.1186/1546-0096-12-13

Cite this article as: Stoll and Cron: Treatment of juvenile idiopathic

arthritis: a revolution in care. Pediatric Rheumatology 2014 12:13.

\section{Submit your next manuscript to BioMed Central and take full advantage of:}

- Convenient online submission

- Thorough peer review

- No space constraints or color figure charges

- Immediate publication on acceptance

- Inclusion in PubMed, CAS, Scopus and Google Scholar

- Research which is freely available for redistribution 